UDC 81'371

DOI: $10.17223 / 24109266 / 63$

\title{
LEXICAL PRAGMATIC MARKERS OF TEMPORAL POSITIONING
}

\author{
Ye.A. Murashova \\ A.P. Chekhov Taganrog Institute (branch) of the federal state budgetary \\ educational institution of higher professional education "Rostov State Economic University" \\ (Taganrog, Russia). \\ E-mail: shenetschka@rambler.ru
}

\begin{abstract}
In this article, the position of temporal lexical markers of the group of constatives in the entire system of the lexical pragmatic markers (such lexical units which reflect various parameters of positioning of the subject of the sender in relation to various facts of the reality represented by it) is revealed. Temporal lexical markers of the group of constatives are distinguished as one of types of markers of this system due to the ability to express the relation of the communicating subjects to the temporal positioning of the objects represented by them and subjects of reality including themselves.

The analysis of lexical pragmatic markers of temporal positioning (temporal lexical markers of group of constatives) is carried out on the material of epistolary texts of the Cossack discourse at the start of the 20th century; first of all, on the material of the Cossack letters of A.I. Dutov, P.N. Krasnov, A.S. Lukomsky and A.M. Sholokhov; also the texts written on behalf of Cossacks and about Cossacks by representatives of the non-Cossack subethnos (I.S. Shmelyov's stories, I.E. Babel's stories, etc.), texts with not personified authors (the Cossack songs "The Letter of the Cossack from military service", the Cossack song "Friends, be not afraid of slander!", etc.).

Lexical pragmatic markers of temporal positioning are analyzed in the article from positions of linguistic pragmatics and taking into account the research conducted earlier by representatives of a linguoculturology, literary criticism, lexical semantics, functional grammar and cognitive linguistics. The linguistic pragmatics is treated in this case as the most perspective direction which creates a basis for understanding of the major form of human activity - the speech communication which is carried out by means of speech signals of various levels (including lexical) with values inherent in them. It promotes formation of continuity between multidirectional branches of scientific knowledge, which in turn inevitably leads to a reflection in the relation, both of a phenomenon of pragmatic meaning, and the principles and methods of its research.
\end{abstract}

Keywords: lexical pragmatic markers; lexical pragmatic markers-constatives; temporal positioning of the communicating subject; the linguopragmatic analysis.

\section{Introduction}

The meanings actualized by temporal lexical markers together with the communicating subject (in the actualized syntactic groups where the active communicating subject is explicated) refer to the group of pragmatic 
meanings like constatives, which we singled out earlier [1: 75-77]. Constatives are pragmatic meanings through whose realization the sender presents one's own temporal and local relation to the presented, and also an individual interpretation of the presented temporary continuum. Pragmatic meanings of this type go back to the temporal deictic reference demonstrating the sender's position in relation to the orientation of interpretation of various temporal factors.

Temporal lexical markers are, first of all, lexemes of temporal positioning - time adverbs, nouns and adjectives containing an assessment of temporal positioning, time conjunctions and time particles, and also verbs of temporal and spatial localization and its change [2: 34-39] that are actualized in the text together with an indication of the active communicating subject. For example, веснусь - last spring, обыдёнки - days, задавний - long ago passed, набежать - to come around for a while, etc.

\section{Research design}

Being actualized within an epistolary Cossack discourse, lexical pragmatic markers of temporal positioning can express the attitude of the speaker to the fact of one's own temporal positioning (a kernel of the temporal deixis) and to the fact and to the fact of temporal positioning of the objects of reality (the periphery of a temporal deixis) presented by the speaker. The fact of one's own temporal positioning is supported with the existence in the actualized syntactic group of a special marker - the index pointing at the active communicating subject (the actual sender). It can be a personal pronoun in the form of the first person singular, the personal pronoun of the first person plural (including in the communication situation of the speaker and someone else), a verb in the form of the first person singular or plural, etc. We will consider actualization of pragmatic markers of temporal positioning on concrete examples (see Examples 1,2).

\section{Example 1}

Между мною и Вами теперь та разница, что Bы имеете много свободного времени для того, чтобы вести беседы и писать длинныя письма и $\mathrm{Bbl}$ отдохнули от своей тяжелой государственной деятельности, я же перегружен работой и не имею ни одной свободной минуты это во-первых.

The difference between me and you now is that you have a lot of free time to conduct conversations and to write long letters and you have had a rest from heavy state activity, and as for me, I am overloaded with work and I have no free minute - that is in the first place [3:173] (hereinafter, the original spelling in examples is preserved). 
In this fragment of the letter by P.N. Krasnov to M.V. Rodzyanko of July 30, 1918, there is simultaneously an expression of the attitude of the speaker to the fact of the speaker's own temporal positioning (a kernel of a temporal deixis) and with an expression of the attitude of the speaker to the fact of the temporal positioning of the depicted subject of reality (the periphery of a temporal deixis).

The reference to the temporal positioning of the actual sender (Ataman P.N. Krasnov) is carried out by means of the personal pronoun of the first person singular and the verb in the form of the present tense of the first person singular linked with a negative pronoun (I have no...), and also a short participle of the perfective aspect (am overloaded) linked with a personal pronoun of the first person singular. The reference to the temporal positioning of the partner in communication (M.V. Rodzyanko) - by means of a polite form of the personal pronoun of the second person singular (by you, you, you) and verbs in the form of the second person singular (you have, have a rest).

The temporal vector of a fragment actualized by a temporal lexical marker - a temporal adverb (now) - is sent to the present. The orientation of a temporal vector in the present is supported by markers of grammatical level category of time of verbs (two verbs in the present, I have, you have).

In the fragment, along with a temporal adverb now, lexical temporal markers - time, minutes, which relate to each other as a holonym to meronym (or to partonym), that is as a whole to a component, are actualized.

Example 2

И я, как дворянин Российской империи, советую Вам не противиться и покинуть облюбованное Вами Войско Донское, где пока спокойно, благодаря вероятно моей глупой политике, так как выселять Вас с конвоем было бы слишком неудобным для Вас и сыграло бы во вред Вашей партии, так как имя Ваше слишком ненавистно казакам и известие о том, что я Вас выслал насильно подняло бы мой престиж, а это Вам не выгодно.

And as a nobleman of the Russian Empire, I advise You not to oppose it and leave chosen by You the Almighty Don Host, where it is so far still quiet, thanks possibly to my silly policy, as it would be too inconvenient for You to expel You with an escort and would do harm to Your party, since Your name is too hateful to Cossacks, and the news that I have expelled You violently would raise my prestige, and it isn't favorable to You [3: 174].

This fragment represents the positioning of the communicating subject - the sender P.N. Krasnov. Besides, the sender marks the temporal positioning of the existing really and possible events - consequences of the carried-out communication. Positioning of the communicating subject sender, 
P.N. Krasnov, is noted by a verb of imperfective aspect in the first person present singular together with the personal pronoun of the first person singular, indicating the active communicating subject ( I advise), his probable actions in the future - a verb of perfective aspect in the first person singular in the past tense also linked with a personal pronoun of the first person singular (I expelled), consequences of this action for the sender - a verb of perfective aspect in the form of the third party singular in subjunctive mood linked with a possessive pronoun of the first person singular (would raise my prestige). The situation of communication is positioned in the present tense by means of an adverb referring the events to the existing at present reality (so far). Positioning on the time axis of the existing really and possible events - consequences of the carried-out communication - verbs of imperfective aspect (would be) and perfective aspect (would do harm) in the third person singular in subjunctive mood. The position of the partner in communication, M.V. Rodzyanko, in the present is brought out of the fragment context (Your name is [at the moment] too hateful to Cossacks, it [at the moment] isn't favorable to You).

In general, the temporal vector of the fragment strives from the present (I advise, while) into the future (would be, would do harm, I expelled [possible action in the future], would raise).

In the given examples, lexical pragmatic markers (now, time, minute, so far) are actualized in close connection with pragmatic markers of other levels of language, first of all, by grammatical ones. In view of the domination of the markers of other levels, lexical pragmatic markers often remain on the periphery of research in various linguistic fields. Nevertheless, it is possible to note a number of interesting works devoted to studying markers of this type.

Thus, representatives of linguoculturology pay much attention to studying lexical temporal markers as parts of complete functional and semantic system of the concept of "time" (along with other parts, morphological and syntactic chronemes - means of representation of time), in the cognitive discourse contour of the literary fiction text (for example, in I.S. Turgenev's texts - see [4]).

Temporal lexical markers are actively investigated in modern literary criticism as one of the main representants of the author's perception of reality, as well as the world outlook and the existence categories, and also creative dominants of the individual style of the author. This research is conducted on the material of works of various authors (for example, I.A. Brodsky see $[5,6])$.

Besides, temporal lexical markers (including, time nouns, time adjectives, adverbs of time and particles of time) are investigated by representatives of lexical semantics as peripheral means of expression of the category of time (the lexico-semantic field of the temporality - the lexico-semantic 
field with a predicative core) in comparison to morphological temporary categories, in particular - with the grammatical category of time of the verb [7]. Such research, undoubtedly, supplements data on speech realization of temporality, but leave open the questions of pragmatic conditionality of updating the lexical means of expression of the category of time within specifically given texts.

As peripheral means of the functional and semantic field of temporality, lexical means of expression of temporal characteristics of events and phenomena (in opposition to the nuclear means of the functional and semantic field of temporality - to the morphological means, namely, aspectualtemporal forms of the verb) are investigated also by representatives of functional grammar, including research with the purpose of detecting the peculiarities of functioning of temporal metaphorical models as a way of disclosure of the language picture of the world of members of a certain language collective [8] and for the purpose of detecting the peculiarities of the ontogenesis of the category of temporality caused by mental and cognitive peculiarities of the speakers [9]. Words whose root morpheme contains the seme of temporality belong to the lexical means of expression of temporary characteristics of events and phenomena [8: 242].

In works of representatives of cognitive linguistics, lexical ways of the embodiment of time are considered in close interrelation with individual and encyclopedic knowledge of participants in communication as means of verbal coding of the fundamental existence concept "time" [10: 4]. Lexical ways of an embodiment of time (also as well as within functional grammar) are marked by representatives of cognitive linguistics as peripheral and studied in close interrelation with grammatical means of verbalization of a concept "time" [Ibid: 10].

The list of research data can be continued; however, from our point of view, despite a big range of works opening various aspects of temporal positioning, the pragmatic aspect can still be considered not fully studied systemically. It means that the use of new methods and techniques for the solution of this problem, including the use of new methods of linguistic pragmatics, is vital.

We will analyze in more detail the lexical pragmatic markers of temporal positioning recorded by us during studying Cossack letters, literary fiction texts stylized after the Cossack letters, and dictionaries, using algorithm of linguopragmatic approach.

\section{Methodology and experiment}

In the group of lexical deictic markers (lexical constatives) by the results of a continuous selection analysis, there were 1808 units. With 983 lexical pragmatic markers of personal positioning, it makes $54.37 \%$ of 
the total number of lexical constatives, 631 lexical pragmatic markers of local positioning $-34.9 \%$ of the total number of lexical constatives and 194 lexical pragmatic markers of temporal positioning $-10.73 \%$. On the chart it looks as follows (Fig. 1).

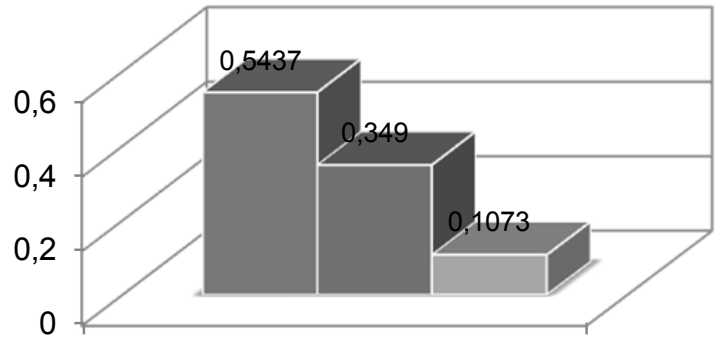

markers of personal
macal pragmatical
positioning
n lexical pragmatical
markers of local
positioning
lexical pragmatical
markers of temporal
positioning

Fig. 1. Lexical constatives of an epistolary Cossack discourse of the beginning of the 20th century

The temporal lexical constatives recorded by us are presented by various parts of speech: time nouns, time adjectives, time verbs, and time adverbs. We singled out set time phrases "pretext + time noun", "adjective + time noun", "time adjective + noun", etc. in a special group.

We will note that during the research no conjunctions of time and time particles were recorded, and, respectively, they weren't included in the analysis presented further.

The generalized data of the analysis of temporal lexical constatives are submitted in the chart (Fig. 2).

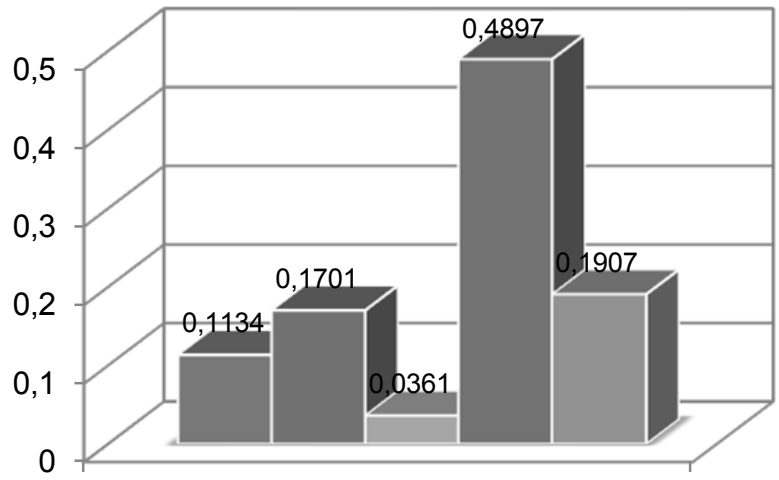

- temporal nouns

- temporal adjectives

- temporal verbs

- temporal adverbs

- temporal phrases

Fig. 2. Temporal lexical constatives

As we see, the most productive lexical pragmatic markers with meaning of temporal localizations of subject / object (objects) are adverbs of time 
(for example, даве - the day before, тады - then, теперича - now). The percentage of actualization of time adverbs makes up $48.97 \%$.

In the second place by the frequency of actualization, there are set temporal phrases (for example, на кочетах - early in the morning, солнце 8 дуб - sunrise, sunset, телячье время - morning cool time, early evening). Time phrases are actualized in $19.07 \%$ of cases.

In the third place, there are adjectives of time (for example, нонешний - present, унагдышний - day before yesterday, хтонатькадашний - existing from time immemorial). Actualization of temporal adjectives is presented as $17.01 \%$.

Nouns of time are in the fourth place (for example, исход - the period of the last phase of the moon, солниесяд - a decline, ужотка - part of day). Temporal nouns are actualized in $11.34 \%$ of cases.

In the last, the fifth place, there were verbs of time (for example, опозниться - to return closer to the night, перелетовать - to live through the summer). The percentage of their actualization makes up 3.61\%.

All temporal pragmatic markers investigated by us are united by a general meaning of temporal positioning, which, in turn, is presented by two subspecies of values - "representation of time as the reality fact" and "positioning of subject / object (objects) on a time base".

As pragmatic temporal lexical markers representing time as the reality fact are ranked:

- the temporal markers referring to time as an essentially natural cycle, for example, бокогрей - February, обыдёнки - days, денной - day, заутро in the morning, на коровьем реву - at dawn, свинячьи полдни - 1011 o'clock in the morning;

- the temporal markers signaling about the duration of a temporal cycle, for example, набежать - to come around for a while, бура - is infinite, обыденно - within one day, сзамальства - since the early childhood, как хохол на отживе - to live by the present, as if serving a term.

The pragmatic temporal lexical markers indicating positioning on a time base are presented by the markers referring the subject / object (objects):

- to the past, for example, полеток - year before last, бувалошный last, задавний - forgotten, long ago passed, ногдашний - day before yesterday, зимусь - last winter, кадысь - once long ago, из предвеку - for a long time, from olden days;

- to the present, for example, нонешний - present, досе - still, зараз now, по цель - still, or

- to the future time, for example, предбудущиии - forthcoming, зарань - in advance, на лето - next summer.

We will calculate the actualization number of each of the presented subtypes of meaning and we will record the thematic classification of temporal lexical markers in the table (Table 1). 
T a ble 1

Thematic distribution of temporal lexical markers of an epistolary Cossack discourse at the beginning of the 20th century

\begin{tabular}{|c|c|c|c|c|}
\hline \multicolumn{2}{|c|}{ Representation of time as reality fact } & \multicolumn{3}{|c|}{ Positioning of subject / object (objects) on a } \\
time base
\end{tabular}

As appears from the table (Table 1), in epistolary Cossack texts, first of all, the temporal lexical markers representing time as the reality fact are actualized. Thus these markers more frequently designate time as a naturally natural cycle - $61(53.51 \%$ of total of the temporal lexical markers representing time as the reality fact), and less frequently mark the duration of this cycle (a current of time, its dynamics) - $53(46.49 \%$ of total of the temporal lexical markers representing time as the reality fact).

According to the table (Table 1), the temporal lexical markers designating positioning of subject / object (objects) on a time base are actualized less than the temporal lexical markers representing time as the reality fact, thus the vector of actualizing the temporal lexical pragmatic markers is considerably displaced in the past $(72.5 \%$ of total of the temporal lexical markers representing positioning of subject / object (objects) on a time base).

The arrangement of lexical pragmatic markers on a time base looks as follows (Fig. 3).

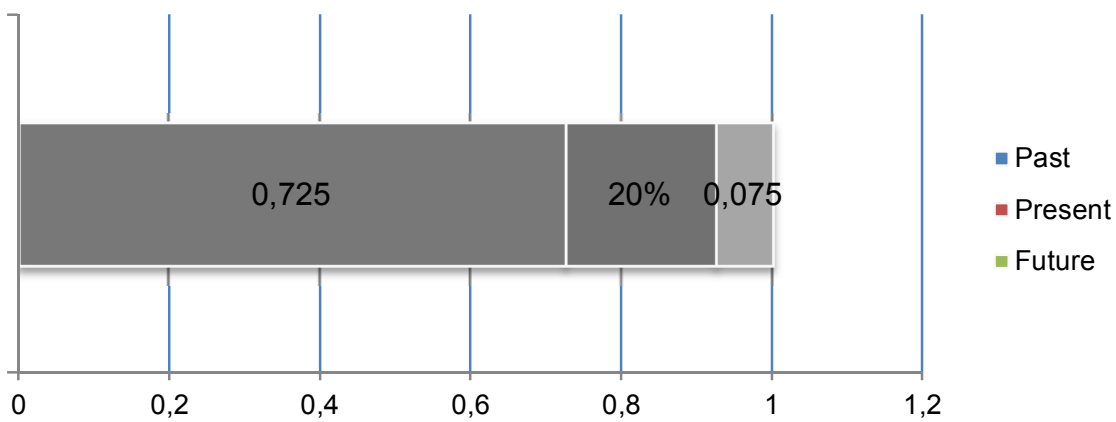

Fig. 3. An arrangement of lexical temporal markers on a time base

Further we will present a classification of the markers indicating positioning on a time base separately, considering the distribution according to parts of speech (Table 2). 
Positioning of subject / object (objects) on a time base

\begin{tabular}{|l|c|c|c|c|}
\hline \multirow{2}{*}{$\begin{array}{c}\text { The relation to parts } \\
\text { of speech / Part of } \\
\text { speech }\end{array}$} & \multicolumn{3}{|c|}{$\begin{array}{c}\text { Positioning of subject / object (objects) on a } \\
\text { time base }\end{array}$} & \multirow{2}{*}{ all } \\
\cline { 2 - 5 } & Past & Present & Future & \\
\hline Temporal nouns & 1 & 0 & 0 & $1(1.25 \%)$ \\
\hline Temporal adjectives & 18 & 2 & 1 & $21(26.25 \%)$ \\
\hline Temporal verbs & 0 & 0 & 0 & 0 \\
\hline Temporal adverbs & 38 & 12 & 5 & $55(68.75 \%)$ \\
\hline Set temporal phrases & 1 & 2 & 0 & $3(3.75 \%)$ \\
\hline \multirow{2}{*}{ Total } & $58(72.5 \%)$ & $16(20 \%)$ & $6(7.5 \%)$ & \\
\cline { 2 - 4 } & \multicolumn{4}{|c|}{$80(100 \%)$} \\
\hline
\end{tabular}

As it is seen from the table (see Table 2), the main means of positioning of subject / object (objects) on a time base are temporal adverbs and temporal adjectives (the temporal adverbs marking positioning on a time base $-68.75 \%$, temporal adjectives marking positioning on a time base $26.25 \%$, temporal phrases marking positioning on a time base $-3.75 \%$, temporal nouns marking positioning on a time base $-1.25 \%$, temporal verbs marking positioning on a time base - 0 ).

Apart from the illustrated hierarchies of actualization of lexical pragmatic markers of time positioning, the following was noted during the linguopragmatic research. Alongside with the nomination of a certain time span some lexical pragmatic markers of the group of constatives in the corresponding context can also indicate position of the communicating subject in space (three such markers are recorded): напередu - 1) ahead, 2) before, neредом - 1) earlier, 2) ahead, попереди - 1) ahead, 2) at first. Such fact confirms the hypothesis of inseparability of the category of time from the category of space (cf. for example, [7: 8]). As the initial spatial meaning (as a reflection of subject reality) in these lexical pragmatic markers, the temporal meaning is considered, which develops on the basis of the spatial meaning.

It is possible to single out separately the temporal lexical markers connected with a religious aspect of life of the Cossack community (four such markers are recorded): сердокрестье - the middle of the Lent, сороки - the ninth of March, day of forty martyrs, сеедная неделя - meat week, Христов день - Easter. Existence of such markers in texts of an epistolary Cossack discourse emphasizes the high level of value of religiousness for the Cossacks at the beginning of the 20th century.

Among temporal lexical markers, we find the diminutive markers - the words and word forms representing temporal positioning of the subject with additional diminutive-hypocoristic value (in the studied texts, nine such markers are recorded): ночушкой - at night, полднички - hook, time from 12 to 14 o'clock, четверок - Thursday, давечка - recently, several hours ago, недавночко - recently, недавнушко - recently, нынечка - nowadays, дё- 
нушки - for days on end, солнышко с полдён - time in the afternoon. These markers indicate a positive evaluation of time which is well influencing subject - eliminating the negative moments of the represented reality, the subject / object (objects), weakening negative emotions.

When studying lexical pragmatic markers of temporal positioning of subject / object (objects), it is necessary to consider the existence of close interrelation with the markers of morphological and syntactic levels of the language. To summarize, by the results of the linguopragmatic analysis of actualization of markers of a temporal reference in epistolary Cossack texts at the beginning of the 20th century, lexical temporal markers take the third place after morphological and syntactic markers (cf. only 575 lexical markers of a deictic temporal reference from 4 337, $13.26 \%)$.

\section{Conclusion}

We will sum up the research results. In this article we presented some prerequisites of research on temporal lexical markers of the group of constatives. Further the markers revealed at the previous investigation phases were subjected to more careful linguopragmatic analysis, which allowed us to reveal the main subspecies of their meanings, to make up a hierarchy of the dominating means of actualization of these subspecies of temporal pragmatic meanings, and also separately to note features of markers, alongside with the temporary localization, representing as well spatial localization, and to designate pragmatic lexical temporal markers of the religious content and pragmatic lexical temporal markers of diminutives.

\section{References}

1. Gorlo, E.A. (2013) To a question of lexical pragmatic markers. Philological sciences. Questions of the theory and practice. 7. (25), 2. Tambov: Diplom. pp. 75-77.

2. Gorlo, E.A. (2012) Deictic reference. Donskoy institute of law: personality, speech and law practice: interuniversity collection of scientific works of the international scientific and methodical conference. Rostov-on-Don: DYuI. 15. pp. 34-39.

3. Krasnov, P.N. (2010) Letters. About dispatch by the Ataman P.N. Krasnov of M.V. Rodzyanko from limits of Vseveliky Army of Donskoy. Archives and documents. The Don Cossacks in fight against Bolsheviks. Almanac. 2. The Art. Elanskaya. Moscow: Moskovskij pechatnyj dvor. pp. 164-183.

4. Ogneva, E.A. (2013) Temporal cognitive grid of the art text: tendencies of cross-cultural adaptation. Modern problems of science and education. Release 3. Belgorod: BGNNIU. [Online]. Available from: http://dspace.bsu.edu.ru/bitstream/123456789/5643/1/ Ogneva_Temporalnaya.pdf.

5. Shtyrlina, E.G. (2012) God in poetic diction of I. Brodsky. The Bulletin of the Udmurt university. Release 2. Izhevsk: YES. pp. 75-82. [Online]. Available from: http://vestnik.udsu.ru/2012/2012-052/vuu_12_052_11.pdf. 
6. Shtyrlina, E.G. (2013) Representation of an art concept "time" in poetic diction of I. Brodsky. Philology Cand. Diss. Kazan: Volga federal university. 180 p.

7. Rusakova, N.V. (2006) Temporally (lexical) and reference properties of the text like "description". Philology Cand. Diss. Ulan-Ude: BGU.

8. Yaroslavtseva, M.V. (2011) Temporal metaphorical models as a way of research of a language picture of the world (on the example of the Russian and Spanish poetic texts). The Young scientist. Kazan: Izdatel'stvo molodoj uchenyj. 4 (1). pp. 242-245.

9. Sudareva, O.G. (2007) Temporal markers in the children's speech. News of the Russian state pedagogical university of A.I. Herzen. SPb: RGPU of A.I. Herzen. 36 (13). pp. 142145.

10. Sinkina, E.V. (2008) Lexical units as era markers (on German material). Philology Cand. Diss. Samara: SGPU. 